\title{
KEARIFAN LOKAL SUKU DAYAK KALIMANTAN DALAM ONTOLOGI CERITA PENDEK BINGKISAN PETIR KARYA KORRIE LAYUN RAMPAN, ED
}

\section{LOCAL WISDOM OF KALIMANTAN DAYAK TRIBES IN SHORT STORY ONTOLOGY OF BINGKISAN PETIR BY KORRIE LAYUN RAMPAN, ED}

\author{
Randa Anggarista \\ Universitas Qamarul Huda \\ Jalan T.G.H. Turmuzi Badaruddin Bagu, Kabupaten Lombok Tengah, Provinsi NTB \\ Ponsel: 082340533987; Pos-el: randaanggarista@yahoo.co.id
}

Naskah Diterima Tanggal: 11 Maret 2021; Direvisi Akhir Tanggal: 14 Juni 2021; Disetujui Tanggal: 25 Juni 2021 DOI: https://doi.org/10.26499/mab.v15i1.451

\begin{abstract}
Abstrak
Penelitian ini merupakan jenis penelitian kualitatif dengan menggunakan perspektif sosiologi sastra. Data dalam penelitian ini berupa teks yang mengacu pada rumusan masalah tentang bentuk kearifan lokal Suku Dayak Kalimantan, sedangkan sumber data dalam penelitian ini yaitu ontologi cerpen Bingkisan Petir karya Korrie Layun Rampan, Ed., yang diterbitkan pada tahun 2005. Instrumen dalam penelitian ini yaitu penulis yang berorientasi pada penelitian tentang bentuk kearifan lokal Suku Dayak Kalimantan dalam ontologi cerpen Bingkisan Petir karya Korrie Layun Rampan. Adapun uji validitas data dalam penelitian ini menggunakan validitas semantis yang berorientasi pada kedalaman proses interpretasi, ketepatan, dan kecermatan analisis berdasarkan perspektif yang digunakan. Teknik pengumpulan data dalam penelitian ini menggunakan teknik baca, catat dan kepustakaan. Teknik analisis data dalam penelitian ini dilakukan dengan tahapan reduksi data, penyajian dan interpretasi data. Hasil penelitian menunjukkan bahwa dalam ontologi cerpen Bingkisan Petir karya Korrie Layun Rampan, Ed., ditemukan adanya representasi kearifan lokal Suku Dayak Kalimantan, yaitu pertama, kearifan lokal pada sistem kesenian berupa musik sampe serta tari nyelamai sakai. Kedua, kearifan lokal pada sistem bahasa berupa bahasa lokal (bahasa ibu) yaitu bahasa banjar. Ketiga, kearifan lokal pada sistem teknologi berupa ketinting sebagai alat transportasi air. Keempat, kearifan lokal pada sistem kepercayaan yang menganut sistem anchestral belief dan the one God. Kelima, kearifan lokal pada sistem mata pencaharian hidup dengan menerapkan sistem perkebunan di tengah kawasan hutan.
\end{abstract}

Kata kunci: kearifan lokal; dayak; dan sosiologi sastra 


\begin{abstract}
This research is a qualitative research using literature of sociology perspective. The data in this research are the form of text that refers to formulation of problem about the form of local wisdom of the Dayak Kalimantan tribe, while the data source in this research is the ontology of the short story Bingkisan Petir by Korrie Layun Rampan, Ed., which was published in 2005. The instrument in this research is the author which oriented to research on the form of local wisdom of the Dayak Kalimantan tribe in the ontology of short story Bingkisan Petir by Korrie Layun Rampan. The data validity test in this study uses semantic validity which oriented to the depth of the interpretation process, accuracy, and accuracy of analysis based on the perspective used. Data collection techniques in this research use reading, notetaking and literature techniques. The data analysis technique in this research was carried out by the stages of data reduction, data presentation and interpretation. The results show that in the short story ontology of Bingkisan Petir by Korrie Layun Rampan, Ed., is found that there are representation of local wisdom of the Dayak Kalimantan tribe, namely first, local wisdom in the art system like sampe music and nyelamai sakai dance. Second, local wisdom in the language system by the use of local language (mother tongue), namely banjar language. Third, local wisdom on technology systems by the use of ketinting as a means of water transportation. Fourth, local wisdom on belief systems that adhere to the ancestral belief system and the one God. Fifth, local wisdom on livelihood systems by applying a plantation system in forest area.
\end{abstract}

Keywords: local wisdom; dayak; sociology of literature

\section{Pendahuluan}

Karya sastra, baik puisi, prosa maupun drama yang berorientasi kearifan lokal merupakan genre sastra yang banyak diminati para penulis, baik peneliti maupun akademisi. Hal itu dibuktikan dengan adanya beberapa penelitian terdahulu yang berusaha mengkaji teks sastra, terutama novel, dengan melihat aspek lokalitas yang terefleksi dalam teks sastra. Beberapa penelitian tersebut misalnya pertama, penelitian yang dilakukan oleh Anggarista (2020) dengan judul "Lokalitas Benuaq Kalimantan dalam Novel Api Awan
Asap Karya Korrie Layun Rampan”. Hasil penelitian menunjukkan bahwa dalam novel Api Awan Asap karya Korrie Layun Rampan terefleksi adanya beberapa bentuk kebudayaan masyarakat Dayak Benuaq Kalimantan, yaitu (a) lokalitas pada sistem kemasyarakatan dengan menerapkan kegiatan musyawarah dan mufakat dalam berbagai persoalan serta menganut sistem kepemimpinan yang dipimpin oleh Petinggi Jepi; (b) lokalitas pada sistem kesenian berupa nyanyian dan menenun kain ulap doyo; (c) sistem mata pencaharian 
hidup dengan mengolah pertanian dan perkebunan; dan (d) lokalitas pada lokasi berupa lou.

Kedua, penelitian yang dilakukan oleh Anggarista (2020b) dengan judul "Representasi Masyarakat Mbojo dalam Cerpen La Riru Karya Mas'oed Bakry". Hasil penelitian menunjukkan bahwa dalam cerpen La Riru karya Mas'oed Bakry terefleksi adanya bentuk kearifan lokal masyarakat Suku Mbojo, Bima, Nusa Tenggara Barat yaitu (a) kearifan lokal pada sistem bahasa yang dibuktikan dengan adanya penggunaan bahasa Mbojo (Nggahi Mbojo); (b) kearifan lokal pada sistem kepercayaan yang menganut kepercayaan dinamisme; (c) serta kearifan lokal pada sistem mata pencaharian hidup dengan mengembangkan pertanian, perkebunan dan peternakan. Beberapa penelitian tersebut merupakan dua di antara banyaknya penelitian lain yang berusaha mengidentifikasi nilai kearifan lokal dalam teks sastra. Sifat kebaruan (novelti) dari penelitian dalam artikel ini terletak pada objek kajian yang digunakan yaitu novel ontologi cerita pendek Bingkisan Petir karya Korrie Layun Rampan, Ed.
Berbagai kajian yang berusaha mengidentifikasi bentuk kearifan lokal suatu daerah menjadi salah satu langkah masif sekaligus sarana untuk mempublikasikan nilai-nilai kearifan lokal dalam sastra agar diketahui masyarakat luas. Penelitian tentang kearifan lokal (warna lokal) perlu dikaji dengan alasan bahwa seiring dengan berkembangnya zaman, terutama perubahan paradigma masyarakat modern yang lebih cenderung terdoktrin dengan teknologi dan berbagai jenis kemudahan yang ditawarkannya, membuat masyarakat modern mulai memberikan anggapan bahwa konsep tradisionalitas tidak relevan dengan konteks perubahan zaman. Selain itu, kearifan lokal yang terdiri dari berbagai elemen, seperti sistem kehidupan yang relevan dengan konsep ekosentrisme perlu dikaji lebih dalam agar mampu memberikan pemahaman tentang etika dalam konsep memanfaatkan sumber daya alam dengan berbagai jenis kekayaannya. Kearifan lokal (warna lokal) sebagai bagian penting dalam konsep tradisionalitas menawarkan prinsip kehidupan yang eksotis, mulai dari etika terhadap alam semesta maupun dengan sesama manusia. 
Kajian yang lebih cenderung kepada usaha untuk memberikan pemahaman kepada seluruh masyarakat tentang etika dan prinsip hidup di tengah ekosistem alam menjadi salah satu arena perjuangan, baik dari aspek sosialis maupun ekologis. Perubahan paradigma masyarakat tradisional menuju ke arah yang lebih konsumtif menjadi alasan penting untuk mengangkat penelitian tentang konsep sosiologi sastra.

Sebagai salah satu perspektif dalam kritik sastra, sosiologi sastra berusaha mengidentifikasi berbagai jenis teks sastra, baik puisi, prosa maupun drama yang merefleksikan konteks kehidupan masyarakat sosial. Abrams (1981) menjelaskan bahwa sosiologi sastra merupakan salah satu perspektif dalam kritik sastra yang bertujuan untuk mengidentifikasi nilai sosial dalam sebuah teks sastra, termasuk kondisi dan kelas sosial, sistem perekonomian, dan politik yang terfleksi dalam teks sastra (hlm. 288). Sebagai sebuah kajian dalam ranah sastra, sosiologi sastra digunakan dalam penelitian ini untuk mengidentifikasi bentuk kearifan lokal Suku Dayak Kalimantan yang terefleksi dalam ontologi cerpen
Bingkisan Petir karya Korrie Layun Rampan, Ed.

Penulis memilih ontologi cerpen tersebut karena setelah melakukan identifikasi terhadap isi teks secara keseluruhan ditemukan adanya gambaran tentang kearifan lokal Suku Dayak Kalimantan yang terefleksi dalam alur cerpen. Kajian tentang kearifan lokal perlu dikaji lebih intens dengan tujuan untuk memberikan wawasan kepada pembaca dan masyarakat umum tentang berbagai bentuk kekayaan Indonesia dari konteks sosio-historis. Ontologi cerpen tersebut terdiri dari enam belas judul cerpen, mulai dari cerpen Nyelama Sakai, Bulan Blues, Amarah Mbah Brangah, Pertemuan Keempat, Siapa Mau ke Surga? Daftar di Sini, Dulak, Dua Surat Salindri, Pensiun, Batu Kokoq, Ketinting Belarut, Kuncilah Bibir dengan Gembok yang Besar, Unas, Mereka memanggilku Marianne, Petir, Kau Tak Salah Lihat Anjani, serta Bingkisan, dengan beberapa penulis yang berbeda. Selain mengangkat tentang kearifan lokal, beberapa cerpen dalam ontologi cerpen tersebut juga memberikan gambaran kedekatan para tokoh dalam teks cerpen dengan lingkungan hidup. 
Sepanjang penelusuran penulis, objek yang digunakan dalam penelitian ini juga tidak pernah diteliti oleh penulis lainnya. Hal itu menjadi alasan penting bagi penulis untuk menggunakan ontologi cerpen Bingkisan Petir karya Korrie Layun Rampan, Ed., sebagai obejk kajian dalam penelitian ini.

Perubahan zaman dan paradigma manusia terhadap konteks lingkungan yang melahirkannya merupakan salah satu bagian penting yang menjadi fokus perhatian pemerintah dan seluruh elemen masyarakat. Seiring berkembangnya zaman, terutama berkembangnya arus modernisasi dengan berbagai produk yang ditawarkannya ikut memberikan dampak terhadap perubahan kondisi masyarakat tradisional. Berbagai elemen penting dalam konteks kebudayaan, secara perlahan mengalami marginalisasi, sehingga hal itu menjadi salah satu bagian penting dari proses lahirnya berbagai teks sastra yang dilahirkan para sastrawan. Mulai dari puisi, prosa dan drama, seringkali memberikan gambaran tentang warna lokal yang dimiliki oleh masing-masing wilayah di Indonesia.
Para sastrawan berusaha menguak kekayaan masyarakat tradisional secara konteks sosiohistoris, terutama yang relevan dengan konsep kebudayaan, untuk memberikan pemahaman kepada seluruh elemen masyarakat. Konsep kebudayaan sebagai salah satu warisan para leluhur perlu dicermati, dipelajari dan dipahami lebih lanjut oleh masyarakat. Teks sastra, terutama cerpen seringkali mengungkapkan berbagai elemen kebudayaan untuk memberikan pemahaman sekaligus sebagai media pembelajaran yang ditujukan kepada para generasi mendatang. Hal itu disebabkan karena teks sastra, baik puisi, prosa maupun drama, tidak pernah lahir tanpa membawa ideologi dan sistem kehidupan masyarakat yang menjadi latar dalam teks tersebut. Teeuw (1980) mengatakan bahwa setiap teks sastra yang lahir ke hadapan pembaca tidak pernah lahir dengan kekosongan budaya (hlm. 11). Artinya bahwa teks sastra mampu diciptakan seorang sastrawan karena berangkat dari realitas sosial yang pernah dialami oleh dirinya sendiri maupun orang lain. 


\section{Landasan Teori}

Sosiologi sastra merupakan salah satu bentuk perspektif dalam kajian sastra yang mengadopsi ilmu sosiologi ke dalam teks sastra. Sosiologi sebagai disiplin ilmu yang berusaha memberikan gambaran tentang kondisi sosial suatu komunitas masyarakat menjadi elemen penting dalam proses pertumbuhan dan perkembangan perspektif sosiologi sastra. Abrams (1981) mengatakan bahwa sosiologi sastra merupakan salah satu perspektif yang mengadopsi ilmu sosiologi ke dalam teks sastra. (hlm. 288). Kajian ini berusaha mengidentifikasi berbagai jenis teks sastra yang memberikan gambaran tentang warna lokal, baik corak, wilayah, kesenian, hingga politik dalam sebuah komunitas masyarakat. Perkembangan dan perubahan paradigma masyarakat menjadi salah satu landasan bagi lahirnya kajian sosiologi sastra. Para sastrawan seringkali mengadopsi aspek sosial suatu komunitas masyarakat menjadi bagian penting yang membengun teks sastra yang dihasilkannya.

Salah satu bagian penting dalam proses implementasi sosiologi ke dalam teks sastra yaitu mengidentifikasi perilaku individu maupun sebuah komunitas. Realitas sosial dan perkembangan masyarakat menjadi sebuah polemik yang terus menarik untuk dikaji. Pendekatan sosiologi sastra dalam ranah kritik sastra menjadi sebuah kajian yang berusaha mengidentifikasi bagaimana perilaku manusia dalam realitas sosial terefleksi dalam sastra. Ratna (2013) menjelaskan bahwa ada beberapa konsep dasar dari sosiologi sastra, yaitu proses memahami kandungan teks sastra dengan mempertimbangkan aspek masyarakat sosial yang terefleksi dalam sastra, serta hubungan antara teks sastra dengan masyarakat yang melatarbelakanginya (hlm. 2). Setiap teks sastra merupakan sebuah manifestasi dari proses pengalaman yang dialami oleh sastrawan maupun orang lain. Oleh karena itu, para sastrawan seringkali mengembangkan alur cerita teks sastra sesuai dengan pemahaman yang dimilikinya sesuai dengan kondisi lingkungan yang melatarbelakanginya. Kondisi dan latar belakang masyarakat menjadi sebuah landasan utama bagi para sastrawan untuk menghasilkan sebuah teks sastra. 
Adapun Wiyatmi (2013) juga memberikan penjelasan tentang perspektif sosiologi sastra yaitu salah satu cara memahami setiap teks sastra dengan memperhatikan aspek sosial yang terefleksi dalam teks sastra (hlm. 5). Hal ini memberikan indikasi bahwa setiap peristiwa yang memberikan corak tersendiri bagi sebuah komunitas masyarakat, baik yang menyangkut aspek kelas sosial, ekonomi, politik, hingga kearifan lokal, menjadi bagian yang tidak terpisahkan dengan sosiologi sastra.

Senada dengan yang
disampaikan Wiyatmi, Faruk (2015) juga mengatakan bahwa pokok persoalan dalam kajian sosiologi sastra adalah adanya perubahan paradigma dan tingkah laku seorang individu yang tercermin dalam teks sastra (hlm.

3). Selain tingkah laku individu, sosiologi sastra juga berusaha mengidentifikasi fakta sosial sebuah komunitas masyarakat, serta paradigma definisi sosial yang berhubungan dengan konsep dan cara individu menanggapi berbagai fakta sosial yang terjadi di tengah lingkungan masyarakat.

Salah satu fokus dalam kajian sosiologi sastra adalah membahas paradigma dasar dari elemen kearifan lokal yang menjadi salah satu unsur kebudayaan. Local color (warna lokal) merupakan salah satu konsep yang memberikan representasi tentang gambaran sebuah wilayah yang terdapat dalam teks sastra. Abrams (1981) menjabarkan bahwa kearifan atau warna lokal berhubungan dengan konsep representasi lokasi, pakaian, maupun benda lainnya dalam teks sastra yang mencirikan sebuah wilayah (hlm. 145). Warna lokal seringkali menjadi salah satu unsur penting yang membangun sebuah teks sastra. Para sastrawan mengadopsi citra sebuah wilayah, mulai dari nama tempat, kesenian, hingga konsep kehidupan lainnya, menjadi tema secara keseluruhan dalam teks sastra.

\section{Koentjaraningrat}

menyebut kebudayaan dan warna lokal sebagai wujud pikiran dan karya dari sebuah komunitas masyarakat yang dihasilkan dalam periode yang panjang (hlm. 11). Konsep kebudayaan diturunkan menjadi beberapa elemen, yaitu pertama, sistem religi yang berhubungan dengan sistem keyakinan sebuah komunitas masyarakat terhadap suatu yang dianggap memiliki kekuatan. 
Kedua, sistem masyarakat yang masyarakat, warna kebersamaan berhubungan dengan konsep kepemimpinan dan seperangkat aturan yang disusun oleh sebuah komunitas masyarakat. Ketiga, sistem pengetahuan berhubungan dengan berbagai hal yang digunakan oleh masyarakat dalam kehidupan seharihari. Keempat, sistem bahasa yaitu berhubungan dengan media yang digunakan oleh sebuah komunitas masyarakat untuk berkomunikasi. Kelima, sistem kesenian berkaitan dengan peralatan musik dan artefak lainnya yang mampu memberikan hiburan kepada masyarakat. Keenam, sistem mata pencaharian hidup berkaitan dengan aktivitas perekonomian yang menjadi sumber kehidupan sebuah komunitas masyarakat. Ketujuh, sistem teknologi berhubungan dengan peralatan sederhana yang memberikan kemudahan bagi masyarakat dalam menjalankan aktivitas.

Pernyataan yang dikemukakan oleh Koentjaraningrat tersebut juga relevan dengan pernyataan yang disampaikan oleh Abdullah (2010) bahwa kearifan lokal memiliki fungsi sebagai identitas sebuah komunitas, aspek yang mengatur pola hidup sebuah komunitas masyarakat, mendorong terciptanya kebersamaan dalam kehidupan masyarakat, dan menjadi sebuah sistem yang menepis berbagai kemungkinan adanya usaha untuk merusak rasa solidaritas (hal. 78).

Sebagai sebuah identitas, kearifan lokal menjadi salah satu ciri khas yang menunjukkan adanya perbedaan dari berbagai elemen penting dalam sistem kearifan lokal. Kearifan lokal mendorong masyarakat agar lebih bersikap harmonis terhadap berbagi nilai adiluhung dalam sistem kehidupan. Hal itu senada dengan yang diungkapkan oleh Sibarani (2012) bahwa kebudayaan bertujuan untuk meningkatkan kualitas kesejahteraan masyarakat. Berbagai elemen penting dalam kearifan lokal perlu dijaga kelestariannya agar tetap menunjukkan eksistensinya di tengah masyarakat (hal. 22).

\section{Metode Penelitian}

Penelitian ini merupakan jenis penelitian kualitatf dengan menggunakan perspektif sosiologi sastra. Data dalam penelitian ini berupa teks, baik kata, frasa, kalimat yang mengacu pada rumusan masalah. 
Sumber data dalam penelitian ini yaitu ontologi cerpen Bingkisan Petir karya Korrie Layun Rampan, Ed., yang diterbitkan oleh penerbit Matahari pada tahun 2005.

$$
\text { Instrumen penelitian yang }
$$
berorientasi pada teks sastra yang tidak melakukan treathment (perlakuan), instrumen yang digunakan adalah peneliti itu sendiri. Oleh sebab itu, instrumen dalam penelitian ini yaitu penulis yang berorientasi pada penelitian tentang kearifan lokal dalam ontologi cerpen Bingkisan Petir karya Korrie Layun Rampan, Ed. Adapun uji validitas data dalam penelitian ini menggunakan validitas semantis yang berorientasi pada kedalaman proses interpretasi, ketepatan, dan kecermatan analisis berdasarkan perspektif yang digunakan.

Teknik pengumpulan data dalam penelitian ini menggunakan teknik baca, catat dan kepustakaan. Teknik baca dalam penelitian ini dilakukan dengan membaca secara keseluruhan isi cerpen dengan tujuan untuk menemukan gambaran tentang data yang diperoleh, sedangkan teknik catat dilakukan dengan mencatat berbagai teks yang relevan dengan sumber masalah dalam penelitian. Adapun teknik kepustakaan dilakukan dengan cara mencari berbagai literatur yang mendukung proses deskripsi dan analisis dalam penelitian.

Teknik analisis data dalam penelitian ini dilakukan dengan tahapan reduksi data, penyajian dan interpretasi data. Reduksi data dalam penelitian ini bertujuan untuk memilih dan memilah berbagai data yang relevan dengan rumusan masalah dalam penelitian, sedangkan penyajian data dilakukan dengan memberikan deskripsi melalui tabel dengan tujuan untuk memberikan gambaran terhadap hasil penelitian. Adapun interpretasi data dilakukan dengan tujuan untuk memberikan pemaknaan terhadap berbagai data yang ditemukan dengan menggunakan berbagai teori yang relevan dengan penelitian.

\section{Pembahasan}

Setelah melakukan identifikasi terhadap teks cerpen, ditemukan adanya representasi kearifan lokal dalam dalam ontologi cerpen Bingkisan Petir karya Korrie Layun Rampan, Ed. Berikut ini penulis paparkan hasi penelitian melalui deskripsi terhadap berbagai data yang ditemukan. Hasil penelitian dan 
pembahasan disajikan melalui tabel berupa bentuk kearifan lokal yang disertai deskripsi dan interpretasi terhadap data yang ditemukan.

\begin{tabular}{|c|c|c|}
\hline No & $\begin{array}{c}\text { Bentuk } \\
\text { Kearifan } \\
\text { Lokal }\end{array}$ & Deskripsi \\
\hline 1. & $\begin{array}{l}\text { Kearifan } \\
\text { Lokal pada } \\
\text { Sistem } \\
\text { Kesenian }\end{array}$ & $\begin{array}{l}\text { Melalui } \\
\text { ontologi cerpen } \\
\text { Bingkisan Petir } \\
\text { ditemukan } \\
\text { adanya indikasi } \\
\text { beberapa data } \\
\text { yang } \\
\text { merefleksikan } \\
\text { jenis kesenian } \\
\text { masyarakat } \\
\text { Dayak } \\
\text { Kalimantan. }\end{array}$ \\
\hline & $\begin{array}{l}\text { Kearifan } \\
\text { Lokal pada } \\
\text { Sistem } \\
\text { Bahasa }\end{array}$ & $\begin{array}{l}\text { Kearifan lokal } \\
\text { pada sistem } \\
\text { bahasa } \\
\text { ditemukan } \\
\text { melalui dialog } \\
\text { antartokoh yang } \\
\text { menggunakan } \\
\text { bahasa Dayak. }\end{array}$ \\
\hline
\end{tabular}

\begin{tabular}{|c|c|}
\hline $\begin{array}{l}\text { 3. Kearifan } \\
\text { Lokal pada } \\
\text { Sistem } \\
\text { Teknologi }\end{array}$ & $\begin{array}{l}\text { Para tokoh } \\
\text { dalam ontologi } \\
\text { cerpen } \\
\text { menggunakan } \\
\text { beberapa jenis } \\
\text { peralatan } \\
\text { sederhana untuk } \\
\text { memberikan } \\
\text { kemudahan } \\
\text { dalam } \\
\text { menjalankan } \\
\text { aktivitas sehari- } \\
\text { hari, terutama } \\
\text { penggunaan } \\
\text { perahu ketinting } \\
\text { untuk }\end{array}$ \\
\hline
\end{tabular}

\begin{tabular}{|c|c|}
\hline & $\begin{array}{ll}\text { mobilitas } & \text { ke } \\
\text { berbagai } & \\
\text { wilayah } & \text { di } \\
\text { Kalimantan. } & \end{array}$ \\
\hline $\begin{array}{l}\text { 4. Kearifan } \\
\text { Lokal pada } \\
\text { Sistem } \\
\text { Kepercayaan }\end{array}$ & $\begin{array}{l}\text { Masyarakat } \\
\text { Dayak yang } \\
\text { terefleksi dalam } \\
\text { teks ontologi } \\
\text { cerpen masih } \\
\text { memiliki } \\
\text { kepercayaan } \\
\text { yang bersifat } \\
\text { animisme } \\
\text { dengan } \\
\text { memberikan } \\
\text { sesembahan } \\
\text { (sesajen) dalam } \\
\text { segala aktivitas } \\
\text { yang mereka } \\
\text { kerjakan. Hal } \\
\text { itu bertujaun } \\
\text { untuk } \\
\text { memberikan } \\
\text { kemudahan dan } \\
\text { keselamatan } \\
\text { bagi kehidupan } \\
\text { para tokoh } \\
\text { secara pribadi } \\
\text { maupun seluruh } \\
\text { elemen } \\
\text { masyarakat. }\end{array}$ \\
\hline
\end{tabular}

mobilitas ke

berbagai

wilayah di

Kalimantan.

kepercayaan

yang bersifat

animisme

dengan

memberikan

sesembahan

(sesajen) dalam

segala aktivitas

yang mereka

kerjakan. Hal

itu bertujaun

untuk

memberikan

kemudahan dan

keselamatan

bagi kehidupan

para tokoh

secara pribadi

elemen

masyarakat. 


\begin{tabular}{ll} 
5. Kearifan & \multicolumn{2}{l}{ Kekayaan hasil } \\
Lokal pada & hutan menjadi \\
Sistem Mata & salah satu \\
Pencaharian & penopang hidup \\
Hidup & bagi para tokoh \\
& dalam ontologi \\
& cerpen. Para \\
& tokoh dalam \\
& teks ontologi \\
& cerpen \\
& menerapkan \\
& sistem \\
& perkebunan \\
& sebagai salah \\
& satu sumber \\
& mata \\
& pencaharian \\
& hidupnya.
\end{tabular}

Setelah memberikan deskripsi temuan dalam sumber data yang digunakan melalui tabel, beikut penulis juga memberikan proses interpretasi terhadap beberapa data yang ditemukan sesuai dengan rumusan masalah dalam penelitian.

\subsection{Kearifan Lokal pada Sistem Kesenian \\ Kearifan lokal pada sistem} kesenian berkaitan dengan artefak dan kesenian lainnya yang mampu memberikan hiburan bagi masyarakat.

Setelah melakukan identifikasi terhadap sumber data secara keseluruhan, dalam ontologi cerpen Bingkai Petir terefleksi adanya gambaran tentang salah satu unsur kearifan lokal pada sistem kesenian.
Hal itu dibuktikan melalui potongan teks data (1) dan (2) berikut ini.

Data (1)

Petikan sampe mulai mendenting-denting. Kanjet nyelamai sakai dimualailah sudah. Dan kembali Ham menyukai lagu keberadaannya di sini. Tarian itu menyambut Ham juga. Dan seperti dulu, Ham selalu akan menunggu dengan hati berdenyar datangnya kanjet manyam tali, karena tarian itu memiliki kekuatan tertentu untuk mengaduk-aduk rasa, seolah melemparkan tali pengikat kepada Ham untuk selalu berada di bawah pengaruh gendamnya sehingga tak bisa keluar dari mencintai tempat ini (Korrie Layun Rampan., 2005:1).

Data (2)

Jangan-jangan, Ham sebetulnya memang ingin, suatu ketika, berkenalan dengan satu dari para penari itu. Mereka akan duduk diam berdua sambil masing-masingnya mencoba meraih pesona. Atau, bercengkerama di lantai ulin. Kuharap ia akan membubuhkan buluh rindu ke gelas minumku (Korrie Layun Rampan., 2005:1).

Salah satu judul dalam ontologi cerpen Bingkisan Petir adalah Nyalama Sakai karya Amien Wangsitalaja. Cerpen ini memberikan kisah tentang romantika seorang pemuda yang mendapat tugas untuk 
bekerja sebagai Pegawai Negeri Sipil di salah satu wilayah Kota Samarinda. Melalui tokoh Ham, Amien Wangsitalaja dengan lugas memberikan gambaran tentang kondisi wilayah Kota Samarinda yang kumuh. Selain menyampaikan kritik terhadap kondisi lingkungan, Amien Wangsitalaja juga menyampaikan kritik terhadap kondisi birokrasi yang tidak tertata rapi. Hal itu dialami oleh tokoh Ham yang notabene sebagai Pegawai Negeri Sipil pada sebuah lembaga riset di Kota Samarinda. Setiap dana yang dikucurkan pemerintah pusat untuk melaksanakan penelitian, selalu mendapat potongan sampai sekian persen.

Selain berusaha menyampaikan kritik, Amien Wangsitalaja juga memberikan representasi tentang salah satu unsur kearifan lokal masyarakat Dayak Kalimantan. Melalui potongan teks data di atas terlihat bahwa setelah resmi menjadi salah satu Pegawai Negeri Sipil, Ham mulai mengenali bagian penting dari sebuah kota di Kalimantan tersebut. Berbagai jenis tarian dan nyanyian khas daerah tersebut mulai mendapat tempat di dalam benak tokoh Ham. Salah satu jenis alat kesenian yang terefleksi dalam data tersebut adalah sampe. Khalish, Murtaza Azizah., (2016) menjelaskan bahwa sampe atau sampeq merupakan salah satu jenis musik tradisional Suku Dayak Kenyah dan Kayaan di Kepulauan Kalimantan. Bentuk alat musik sampe seperti gitar yang dimainkan dengan cara dipetik. Sampe memiliki arti memetik dengan jari (hlm. 22).

Narasi yang disampaikan oleh Amien Wangsitalaja melalui salah satu cerpen tersebut mmeberikan gambaran kepada pembaca bahwa Kalimantan sebagai salah satu wilayah kepulauan terbesar di Indonesia memiliki warna lokal yang khas sekaligus menjadi identitas bagi komunitas masyarakat di wilayah tersebut. Sampe sebagai salah satu alat musik tradisional yang dimiliki oleh masyarakat Dayak Kalimantan, khususnya Dayak Kenyah dan Kayaan menjadi bagian penting yang membangun teks cerpen secara keseluruhan. Selain alat musik, Amien Wangsitalaja juga memberikan representasi tentang salah satu jenis kearifan lokal Suku Dayak Kalimantan yaitu adanya tarian-tarian yang bersifat khas. Salah satu jenis tarian yang terefleksi sesuai dengan data di atas yaitu tari nyelamai sakai. Tarian 
ini merupakan salah satu jenis tarian tradisional yang biasanya dilakukan untuk menyambut tamu. Nyelamai Sakai dibawakan oleh sekelompok komunitas, baik laki-laki maupun perempuan dengan jumlah yang banyak. Hal itu memberikan gambaran adanya kekayaan warna lokal yang bersifat eksotis sekaligus sebagai media yang mampu memberikan hiburan kepada masyarakat lokal maupun para pendatang. Alat musik sampe dan tari nyelamai sakai merupakan dua ikon penting bagi kehadiran masyarakat Dayak Kalimantan di tengah arus modernisasi.

\subsection{Kearifan Lokal pada Sistem Bahasa}

Selain memberikan representasi tentang kearifan lokal pada sistem kesenian, dalam kumpulan cerpen Bingkisan Petir juga terefleksi adanya representasi kearifan lokal Dayak Kalimantan yaitu dari segi sistem bahasa. Hal itu dibuktikan melalui beberapa potongan teks data (3), (4) dan (5) berikut ini.

\section{Data (3)}

“... Nah, kau pintar, Naf. Dan kepintaranmu makin mendorongku untuk muyak dengan semua ini..." (Korrie Layun Rampan., 2005:6).
Data (4)

"Tak ada jalan lain. Ribuan tahun masyarakat sini dijajah penyakit kebodohan. Bagaimana mungkin mengobati orang sakit TBC atau Lepra dengan belian? Indonesia sudah merdeka tapi masyarakat sini belum merdeka!" (Korrie Layun Rampan., 2005:72).

\section{Data (5)}

Besok malamnya Run berangkat menuju muara bersama rombongan peluntaan, perenggean, dan pehampangan. Run sendiri termasuk pengguna jala dan rengge... (Korrie Layun Rampan., 2005:84).

Setelah melakukan identifikasi terhadap teks cerpen, penulis juga menemukan adanya representasi tentang kearifan lokal pada sistem bahasa. Melalui potongan teks data di atas terlihat bahwa penulis cerpen berusaha menggunakan diksi bahasa daerah, terutama bahasa Dayak Kalimantan. Berdasarkan potongan teks data (3) di atas terdapat penggunaan diksi muyak yang digunakan oleh cerpenis sendiri. Muyak merupakan salah satu diksi dalam Bahasa Banjar Kalimantan yang artinya bosan. Amien Wangsitalaja selaku penulis cerpen berusaha memberikan deskripsi melalui tokoh Ham yang telah jatuh cinta pada kekasihnya yaitu Naf. Perasaan 
cintanya ternyata seperti tidak mendapat respon positif dari si tokoh perempuan dalam cerpen. Hal itu membuat Ham merasa bosan dengan segala perjuangan yang telah dikorbankannya untuk si kekasih.

Selain pada potongan teks data (3), dalam data (4) di atas juga terefleksi adanya representasi kearifan lokal masyarakat Dayak Kalimantan pada sistem bahasa. Melalui cerpen Batun Kokoq sebagai salah satu judul dalam ontologi cerpen Bingkisan Petir, Korrie Layun Rampan berusaha memberikan gambaran kepada pembaca dan masyarakat luas tentang kondisi masyarakat Dayak Kalimantan yang mengalami marginalisasi. Seiring berkembangnya zaman, terutama dengan maraknya kasus eksploitasi alam di Kepulauan Kalimantan, ikut menjadi bagian penting yang berusaha disampaikan oleh Korrie melalui cerpen tersebut.

Selain kerusakan ekosistem, Korrie juga berusaha memberikan kritik sosial akibat minimnya fasilitas kesehatan yang mampu menunjang keselamatan masyarakat setempat. Adanya paham tradisionalitas, terutama pada sistem keyakinan yang masih memegang erat konsep animisme dan dinamisme, menjadi salah satu media alternatif bagi masyarakat setempat untuk mengobati berbagai jenis penyakit yang mereka derita, salah satunya yaitu TBC. Kepercayaan terhadap sistem tradisionalisme menjadi bagian penting yang membangun kehidupan masyarakat Dayak Kalimantan secara konteks sosio-historis. Melalui potongan teks data di atas terlihat bahwa ketika masyarakat Dayak Kalimantan menderita penyakit, mereka berusaha mengobati penyakitnya kepada seorang belian Istilah belian atau balian atau wadian merupakan salah satu diksi bahasa Suku Benuaq di Kalimantan Tengah. Belian berarti sebuah prosesi pengobatan bagi masyarakat setempat. Pada prosesi belian terdapat berbagai mantra yang diyakini mampu menyembuhkan penyakit di tengah kalangan masyarakat Suku Benuaq dan Suku Bukit di Provinsi Kalimantan Tengah.

Teks data (5) di atas juga memberikan indikasi adanya sistem bahasa lokal yang digunakan pengarang untuk membangun cerita dalam cerpennya. Melalui cerpen Ketinting Belarut, ditemukan adanya 
salah satu diksi yang mencirikan sistem bahasa masyarakat Dayak Kalimantan yaitu peluntaan, perenggean, pehampangan, serta rengge. Pada sistem bahasa Dayak Kalimantan sesuai yang terefleksi dalam cerpen Ketinting Belarut, keempat diksi tersebut termasuk salah satu morfem dalam bahasa Dayak Kalimantan. Peluntaan berarti para penjala, perenggean berarti para pemasang jaring, pehampangan yaitu para nelayan empang, sedangkan rengge artinya jaring.

Diksi bahasa ibu (lokal) sesuai dengan alur cerita dalam teks cerpen menjadi indikasi adanya keragaman lokalitas yang dimiliki oleh masyarakat Kalimantan. Kearifan lokal pada sistem bahasa ditemukan dalam alur cerita teks cerpen secara keseluruhan serta dalam dialog yang terjadi antar tokoh. Diksi bahasa lokal yang terefleksi dalam cerpen berfungsi sebagai alat komunikasi sekaligus interaksi masyarakat yang tergambar dalam teks cerpen. Korrie Layun Rampan bersama penulis lainnya dalam ontologi cerpen tersebut berusaha memberikan pemahaman kepada pembaca bahwa masih banyak lagi kekayaan atau kearifan lokal yang perlu mendapat perhatian secara utuh, baik dari masyarakat sipil maupun pemerintah pemegang birokrasi. Seiring berkembanya zaman, beberapa jenis bahasa lokal yang terdapat di wilayah Indonesia mulai mengalami kepunahan. Oleh karena itu, representasi tentang kearifan lokal pada sistem bahasa dalam teks cerpen tersebut sebagai salah satu media perjuangan agar bahasa Banjar, Benuaq dan bahasa daerah lainnya tidak mengalami kepunahan serta tetap menunjukkan eksistensinya.

\subsection{Kearifan Lokal pada Sistem Teknologi \\ Selain sistem kesenian dan} bahasa, dalam ontologi cerpen Bingkisan Petir ditemukan adanya representasi tentang kearifan lokal dalam sistem teknologi yaitu penggunaan berbagai peralatan sederhana yang mampu memberikan kemudahan bagi tokoh dalam teks sastra. Hal itu dibuktikan dengan potongan teks data (6) berikut ini.

\section{Data (6)}

... 'Maaf, boleh saya tahu nomor Hp-nya?' begitu formal cara bicaramu, seakan aku di kutub utara dan kau di selatan, tak ada ketinting hati yang dapat menghubungkannya... (Korrie Layun Rampan., 2005:30). 
Kepulauan Kalimantan yang memiliki berbagai komunitas (suku) tentu saja hadir dengan ciri khasnya masing-masing. Selain pada sistem kesenian dan bahasa, dalam ontologi cerpen Bingkisan Petir juga terefleksi adanya kearifan lokal Dayak Kalimantan pada sistem teknologi. Sistem teknologi berkaitan dengan peralatan sederhana yang mampu memberikan kemudahan bagi setiap aktivitas yang dilakukan oleh masyarakat setempat. Berdasarkan potongan teks data di atas terlihat bahwa tokoh dalam teks cerpen menggunakan ketinting sebagai alat transportasi yang menghubungkannya dengan wilayah lain di Kalimantan. Melalui cerpen Pertemuan Keempat karya Atik Sulityowati yang termuat dalam ontologi cerpen Bingkisan Petir terefleksi bahwa ketinting menjadi salah satu transportasi tradisional yang diguanakan masyarakat Dayak Brusu di Kalimantan Timur untuk melakukan mobilisasi ke berbagai wilayah lainnya. Para tokoh dalam teks cerpen menggunakan peralatan sederhana sebagai salah satu penunjang kehidupannya. Ketinting berbentuk perahu yang biasanya terbuat dari kayu ulin sebagai salah satu komoditas di Kepulauan Kalimantan. Kalimantan sebagai salah satu wilayah kepulauan yang terdiri dari berbagai sungai yang tergolong besar membuat masyarakat setempat menggunakan alat transportasi tradisional berupa ketinting sebagai media yang mampu memberikan kemudahan dalam segala aktivitas yang mereka lakukan.

Teks data (6) di atas sekaligus memberikan refleksi tentang kreativitas yang dimiliki masyarakat Dayak di wilayah Kepulauan Kalimantan. Selain sebagai alat transportasi sungai, masyarakat Dayak Kalimantan juga seringkali mengguakan ketinting sebagai alat transportasi di tengah laut dangkal. Bentuk ketinting yang aerodinamis, membuat para nelayan memfungsikan ketinting dalam aktivitas menagkap atau menjala ikan.

\subsection{Kearifan Lokal pada Sistem Kepercayaan}

Setelah melakukan identifikasi terhadap sumber data, dalam ontologi cerpen Bingkisan Petir juga ditemukan adanya representasi kearifan lokal masyarakat Dayak Kalimantan pada sistem kepercayaan. Hal itu dibuktikan melalui potongan teks data berikut ini.

Data (7) 
Di langit jingga bulan mengembang menyambut malam. Malam Jumat kliwon, malam keramat bagi penduduk Dukuh Pawingitan, pada setiap malam keramat ini, para penghuni Dukuh Pawingitan harus menyiapkan sesajen pitung warna, yaitu sejodho kemenyan, kembang telon, jadah putih kuning, setangkep gula aren, selirang pisang raja, kinangan, dan sebutir telur ayam kampung ireng mulus... (Korrie Layun Rampan., 2005:16).

\section{Data (8)}

"Jin, setan, peri prayangan, sirna denging sesajen pitung warna!" Japa mantera Mbah Brangah mengusir lelembut yang diyakini menghuni batu besar di bawah pohon asam di pategalan Dukuh Pawingitan (Korrie Layun Rampan., 2005:16).

Selain pada sistem kesenian, bahasa dan teknologi, dalam ontologi cerpen Bingkisan Petir juga ditemukan adanya representasi kearifan lokal Dayak Kalimantan pada sistem kepercayaan. Melalui potongan teks data di atas terlihat bahwa masyarakat Dayak Kalimantan sebagai salah satu unsur pembangun teks cerpen digambarkan masih menekankan pada kepercayaan yang bersifat tradisional. Berdasarkan teks data pertama terlihat bahwa setiap malam Jumat, para tokoh dalam teks cerpen setiap saat menyiapkan sesajen pitung warna yang dipersembahkan untuk arwah leluhur di wilayah tersebut. Selain memberikan persembahan berupa sesajen, para tokoh juga mengguanakan mantera untuk mengusir roh jahat yang berusaha mengganggu kehidupan masyarakat setempat.

Adanya sistem kepercayaan yang bersifat tradisionalitas sesuai dengan teks tersebut memberikan indikasi bahwa masyarakat dalam teks cerpen berusaha menanamkan dua konsep sistem keyakinan yaitu anchestral belief dan the one God. Anchestral belief berkaitan dengan sistem kepercayaan terhadap arwah nenek moyang dan benda yang dianggap memiliki kekuatan. Salah satu cara dilakukan masyarakat setempat yaitu dengan melakukan pujaan melalui persembahan sesajen untuk meminta keselamatan. Selain anchestral belief, masyarakat Dayak Kalimantan juga menganut sistem kepercayaan the one God yaitu sistem kepercayaan terhadap Tuhan Yang Maha Satu. Masyarakat Dayak Kalimantan juga memiliki anggapan bahwa Tuhan juga memiliki kekuatan 
dan kekuasaan tertinggi dalam kehidupan manusia. Salah satu implemntasi dari sistem keyakinan tersebut adalah dengan melakukan peribadatan sesuai dengan tuntutan ibadah.

\subsection{Kearifan Lokal pada Sistem Mata Pencaharian Hidup}

Selain sistem kesenian, bahasa, teknologi dan kepercayaan, dalam ontologi cerpen Bingkisan Petir juga ditemukan adanya representasi tentang kearifan lokal Dayak Kalimantan pada sistem mata pencaharian hidup. Berdasarkan hasil identifikasi terhadap teks cerpen, ditemukan adanya representasi kearifan lokal Dayak Kalimantan pada sistem mata pencaharian hidup. Hal itu dibuktikan melalui potongan teks data berikut ini.

\section{Data (9)}

Tideng Pale kaya akan kepolosan alam, begitu mudahnya mendapatkan segala sesuatu dari alam, karena masyarakat Dayak Berusu yang ada di dalamnya pun sangat menjaga keseimbangan alam. Penuh kemurnian, kepolosan, dan sikap terbuka mereka menerima kedatanganku, itu yang membuat aku betah dapat berlama-lama tinggal di kalangan masyarakat Dayak Berusu... (Korrie Layun Rampan., 2005:24).
Sistem mata pencaharian hidup berkaitan dengan sumber perekonomian masyarakat setempat sekaligus menjadi penopang kehidupan. Data di atas merupakan potongan teks dalam cerpen Pertemuan Keempat karya Atik Sulistyowati. Sebagai salah satu bagian dalam ontologi cerpen Bingkisan Petir, dalam Pertemuan Keempat, pengarang memberikan gambaran tentang kedekatan masyarakat Dayak Berusu Kalimantan dengan alam. Berbagai jenis kekayaan hutan, seperti kayu, sayur-sayuran, buah-buahan, serta aneka fauna lainnya menjadi penopang kehidupan masyarakat setempat. Sistem kehidupan yang tidak bisa melepaskan diri dari kekayaan alam, membuat masyarakat setempat sesuai dengan teks cerpen berusaha menjaga dan menyelamatkan ekosistem alam yang mereka tinggali. Seiring dengan berkembangnya zaman, terutama berdirinya berbagai perusahaan kayu di tengah kawasan hutan, membuat kehidupan masyarakat Dayak Berusu menjadi terancam. Berbagai sistem kehidupan yang berorientasi terhadap usaha menyelamatkan lingkungan hidup diterapkan oleh masyarakat 
setempat. Salah satunya yaitu sikap hormat terhadap alam yang diaktualisasikan dengan membiarkan makhluk hidup di tengah ekosistem alam untuk tumbuh dan berkembang sesuai dengan kodrat penciptaannya.

Kutipan teks data tersebut sebagai salah satu wujud penghormatan para tokoh terhadap alam, sehingga kondisinya tetap terjaga. Hal itu bertujuan agar alam sebagai salah satu sumber perekonomian tidak mengalami kerusakan, sehingga masyarakat dapat memanfaatkannya secara kontinuitas. Sistem perekonomian yang masih berorientasi pada hasil hutan seharusnya juga sejalan dengan usaha yang berusaha menyelamatkannya dari berbagai jenis kerusakan, terutama pembalakan liar. Selain sebagai wujud terima kasih, sikap hormat terhadap alam juga sebagai wujud syukur kepada Tuhan sebagai pemilik alam itu sendiri.

\section{Penutup}

Berdasarkan hasil analisis dan pembahasan dapat disimpulakan bahwa dalam ontologi cerpen Bingkisan Petir karya Korrie Layun Rampan ditemukan adanya representasi kearifan lokal Dayak
Kalimantan yaitu pertama, kearifan lokal pada sistem kesenian berupa musik sampe serta tari nyelamai sakai. Kedua, kearifan lokal pada sistem bahasa berupa bahasa lokal (bahasa ibu) yaitu bahasa banjar. Ketiga, kearifan lokal pada sistem teknologi berupa ketinting sebagai alat transportasi air. Keempat, kearifan lokal pada sistem kepercayaan yang menganut sistem anchestral belief dan the one God. Anchestral belief berkaitan dengan sistem kepercayaan terhadap arwah nenek moyang dan benda yang dianggap memiliki kekuatan. Adapun the one God yaitu sistem kepercayaan terhadap Tuhan Yang Maha Satu. Kelima, kearifan lokal pada sistem mata pencaharian hidup dengan menerapkan sistem perkebunan di tengah kawasan hutan.

\section{Daftar Pustaka}

Abdullah, Irwan. 2010. Konstruksi dan Reproduksi Kebudayaan (hlm. 78). Yogyakarta: Pustaka Pelajar.

Abrams, M. 1981. A Glossary of Literary Terms (hlm. 145, 288, 288). New York: Holt, Rinehart, and Winston.

Anggarista, R. 2020a. Lokalitas Benuaq Kalimantan Dalam Novel Api Awan Asap Karya Korrie Layun Rampan. Fon: Jurnal 
Pendidikan Bahasa dan Sastra Indonesia, 16 (1), hlm. 47-56.

Anggarista, R. 2020b. Representasi Masyarakat Mbojo Dalam Cerpen La Riru Karya Mas'oed Bakry. PENAOQ: Jurnal Sastra, Budaya dan Pariwisata, 1 (1), hlm. 1-8.

Faruk. 2015. Pengantar Sosiologi Sastra (hlm. 3). Yogyakarta: Pustaka Pelajar.

Khalish, Murtaza Azizah., et all. 2016. Pengaruh Alunan Musik Sampeq Sebagai Terapi Stres. Psikostudia: Jurnal Psikostudia Universitas Mulawarman, 5 (1), hlm. 19-28.

Koentjaraningrat. 1994. Kebudayaan, Mentalitet dan Pembangunan (hlm. 11). Jakarta: Gramedia Pustaka Utama.

Korrie Layun Rampan., E. 2005. Bingkisan Petir (hlm. 1, 1, 6, 16, 16, 24, 25, 27, 29, 30, 72, 84). Yogyakarta: Matahari.
Ratna, N. K. 2013. Paradigma Sosiologi Sastra (hlm. 2). Yogyakarta: Pustaka Pelajar.

Sibarani, Robert. 2012. "Folklor sebagai Media dan Sumber Pendidikan: Sebuah Ancangan Kurikulum dalam Pembentukan Karakter Siswa Berbasis Nilai Budaya Batak" dalam Kearifan Lokal: Hakekat, Peran, dan Metode Tradisi Lisan (hlm. 22). Yogyakarta: Lontar.

Teeuw, A. 1980. Tergantung Pada Kata (hlm. 11). Jakarta: Pustaka Jaya.

Wiyatmi. 2013. Sosiologi Sastra (hlm. 5).Yogyakarta: Kanwa Publisher . 